Environmental Research Journal 5 (3): 117-120, 2011

ISSN: 1994-5396

(C) Medwell Journals, 2011

\title{
Radon and Radium Concentrations in 120 Samples of Drinking, Springs and Rivers Water Sources of North West Regions of Mashhad
}

\author{
${ }^{1} \mathrm{~A}$. Binesh and ${ }^{2} \mathrm{H}$. Arabshahi \\ ${ }^{1}$ Department of Physics, Payam Nour University, Fariman, Iran \\ ${ }^{2}$ Department of Physics, Ferdowsi University of Mashhad, Mashhad, Iran
}

\begin{abstract}
Radon makes up approximately half of the total dose of radiation were receive naturally. The majority of it comes from the inhalation of progeny of ${ }^{222} \mathrm{Rn}$ and is prominent in a closed atmosphere. The continuous measurement of the levels of ${ }^{222} \mathrm{Rn}$ concentration in different geographical areas is of great importance, particularly in living places. In this study, the concentration of radium and radon in 120 samples of drinking, springs and rivers water sources of north west regions of Mashhad city have been measured. Solid state nuclear track detectors were used for measuring the concentration. The average value of radon and radium concentrations in the studied area is found to be $30.2 \pm 5.1$ and $18.4 \pm 2.2 \mathrm{~Bq} \mathrm{~m}^{-3}$, respectively. The dose rate due to radon, radium and their progenies received by the population in the studied location between 0.1-0.5 mSv year ${ }^{-1}$. The arithmetic and geometric mean concentrations are $0.2 \pm 0.05$ and $0.2 \mathrm{mSv}_{\text {year }}{ }^{-1}$, respectively. The results show no significant radiological risk for the inhabitants of the studied regions.
\end{abstract}

$\underline{\text { Key words: } \text { Radon and radium concentrations, water sources, radiation, location, population, Iran }}$

\section{INTRODUCTION}

There is much concern these days on the part of the public and government organizations about natural radiation and the environment, particularly for dwellings (Folger et al., 1994). Due to relatively higher doses found as a consequence of elevated radon concentrations some countries are now passing legislation to deal with the problem.

This is true particularly in cold climate countries where the energy crisis is a serious problem and where houses were built more hermetically so as to minimize ventilation conditions. Radon contributes most to the effective dose received by a population from natural sources.

It has been estimated that radon and its progeny contribute three-quarters of the annual effective dose received by human beings from natural terrestrial sources and are responsible for about half of the dose from all sources. Radon emanates to a certain degree from all types of soil and rocks (Al-Kazwini and Hasan, 2003).

The presence of ${ }^{222} \mathrm{Rn}$ in the biosphere is due to its semi-disintegration period of 3.8 days which allows it to diffuse from the earth's crust into the atmosphere (Khan, 2000). The radiological importance of radon does not depend on the concentration of radon gas itself but on its short-lived decay progenies such as polonium, bismuth and lead. During breathing, radon is exhaled but the progenies being material particles may deposit on to the lungs, tracks of breathing etc. (Kearfott, 1989). Some factors that influence the diffusion of radon from soil into the air are the existence of uranium and radium in soil and rock, emanation capacity of the ground, porosity of the soil and rock, pressure gradient between the interfaces, soil moisture and water saturation grade of the medium. Radon can enter to the body via respiring, drinking and eating.

The alpha emitted by this radon and other radiation emitted from its decay products increase the absorbed dose in respiratory and digestion systems (Kendal and Smith, 2002). Nearly 50\% of annually radiation dose absorption of human is due to radon which is one of the main cancers cause at respiratory and digestion systems (Li et al., 2006). Radon in water can enter the human body in two ways.

Firstly, radon in drinking water or mineral drinks can enter the human body directly through the gastrointestinal tract and irradiate whole body which the largest dose being received by the stomach (Kusyk and Ciesla, 2002).

Assuming an average consumption of $0.5 \mathrm{~L}$ of water per person per day and stomach dose per $\mathrm{Bq}$ of radon is $5 \mathrm{nGy} / \mathrm{Bq}$ with the consider 0.12 for stomach tissue weighting factor and 20 for quality factor of $\alpha$-radiation, the annual equivalent dose per $\mathrm{Bq}$ of radon concentration in water is about $2.19 \times 10^{-6} \mu \mathrm{Sv} /($ year $\mathrm{Bq} \mathrm{L}$ ). Secondly, radon can escape from household water and became as an indoor radon source which then enter the human respiratory tract system to deliver radiation dose.

Corresponding Author: A. Binesh, Department of Physics, Payam Nour University, Fariman, Iran 


\section{MEASUREMENT METHODS}

In this study, radon was measured in the water samples using PRASSI system (Savidou et al., 2001). A total of 120 samples including 38 samples of drinking water, 56 river water samples and 26 samples of spring waterwater were tested. Figure 1 shows the sampling sites.

Radium in the water samples were measured keeping the water samples in the bottles for 35 days to let radon reach the equilibrium with radium whereby we obtained radium concentration in the samples.

Figure 2 shows the system set up of measurement including bubbler and drier column. PRASSI pumping circuit operates with constant fallow rate at $3 \mathrm{~L} \mathrm{~min}^{-1}$ in order to degassing the water sample properly. Its detector is a scintillation cell coated with $\mathrm{ZnS}(\mathrm{Ag}) 1830 \mathrm{~cm}^{3}$ volume. The sensitivity of this system in continuous

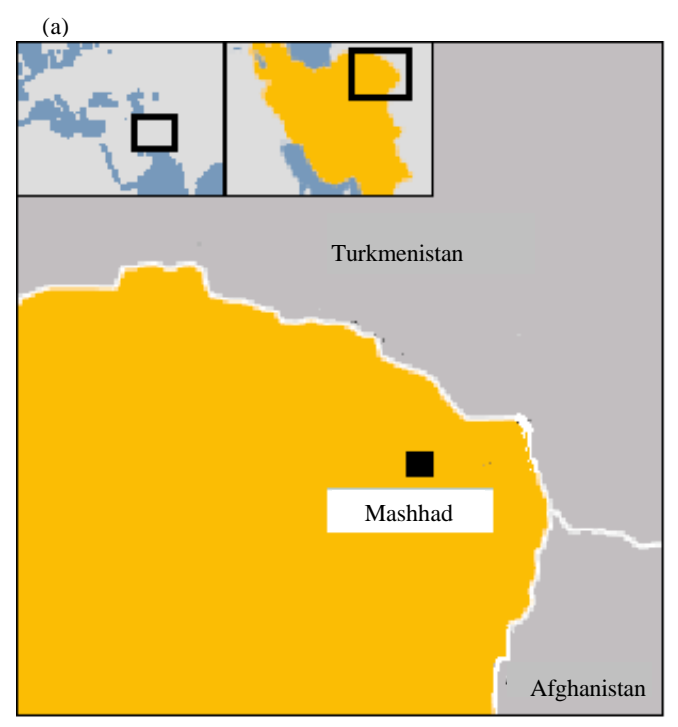

(b)

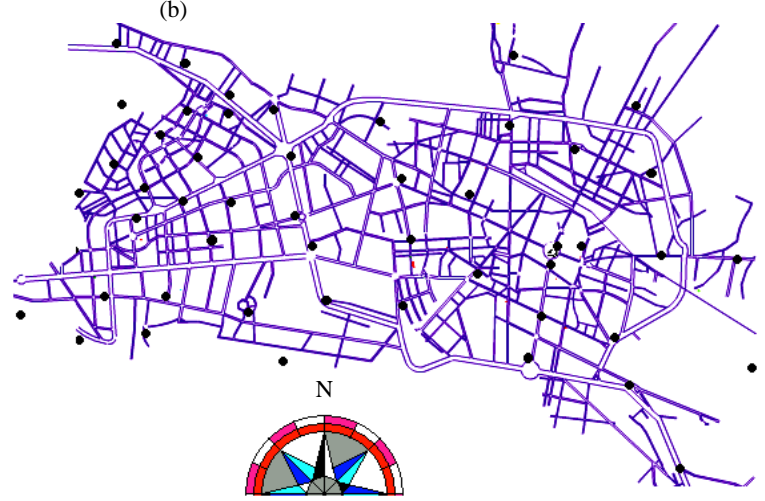

Fig. 1: (a) Mashhad location in Iran; (b) the map of Mashhad city and $\cdot$ shows the sampling sites of Zoshk, Shandiz and Torghabeh mode is $4 \mathrm{~Bq} \mathrm{~m}{ }^{-3}$ during the integration time $1 \mathrm{~h}$. Numbers shown by the device is based on $\mathrm{Bq} \mathrm{m}^{-2}$. Using relationship Eq. 1, radon gas density is calculated based on $\mathrm{Bq} / \mathrm{L}$.

$$
\mathrm{Q}_{\mathrm{Rn}}\left(\frac{\mathrm{Bq}}{\mathrm{L}}\right)=\mathrm{Q}_{\mathrm{PRASSI}} \times \frac{\operatorname{Vtot}\left(\mathrm{m}^{3}\right)}{\mathrm{V}(1)} \times\left[\exp \left(\frac{\operatorname{Ln} 2}{3.8 \times 24} \mathrm{t}\right)\right]
$$

Where:

$\mathrm{Q}_{\text {PRASSI }}=$ Recorded by the device

$V_{\text {tot }}=$ The total volume of air connections

$\mathrm{V}=$ Volume sample and within the brackets is a correction factor in the delay measurement

Radon in water samples: The third column in Table 1 , radon concentration samples that have been ordered from low to high is listed. Also, the radon gas density results are shown in histogram of Fig. 3.

As it can be shown only $81 / 12 \%$ of the samples the last 19 samples in Table 1 have concentrations $>11 \mathrm{~Bq} \mathrm{~L}^{-1}$, particularly the sample number 120 that related to the spring in the village of Zoshk has concentration about $30 \mathrm{~Bq} \mathrm{~L}^{-1}$.

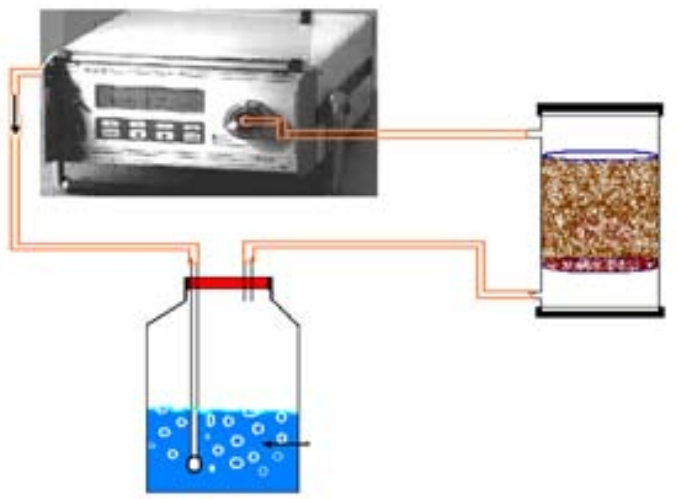

Fig. 2: The PRASSI system set up for radon measuring in the water samples

Table 1: Radon and radium concentration data of different water samples

\begin{tabular}{lcc} 
Water samples & $\mathrm{Q}_{\mathrm{Rn}}(\mathrm{Bq} / \mathrm{L})$ & $\mathrm{Q}_{\mathrm{Ra}}(\mathrm{Bq} / \mathrm{L})$ \\
\hline Zoshk river & 0.000 & 0.000 \\
River 10 km before Zoshk & 0.000 & 0.230 \\
River 2 km before Zoshk & 0.000 & 0.000 \\
River 8 km before Zoshk & 0.000 & 0.240 \\
River 1 km after Zoshk & 0.000 & 0.150 \\
River 4 km after Zoshk & 0.300 & 0.000 \\
Zoshk spring water & 0.330 & 0.000 \\
Zoshk drinking water (No. 1) & 0.320 & 0.045 \\
River 1.5 km after Zoshk & 0.380 & 0.090 \\
Torghabeh drinking water (No. 1) & 0.540 & 0.000 \\
River of shandiz waterfall (No.1) & 0.560 & 0.680 \\
River 2.3 km after Torghabeh & 0.580 & 0.080 \\
River 2.5 km after Zoshk & 0.600 & 0.050 \\
\hline
\end{tabular}


Environ. Res. J., 5 (3): 117-120, 2011

Table 1: Continue

Water samples

River $1.3 \mathrm{~km}$ after Zoshk

Zoshk drinking water (No. 2)

Shandiz waterfall

River $2.8 \mathrm{~km}$ after Abrdh

River $0.8 \mathrm{~km}$ after Zoshk

River $1.8 \mathrm{~km}$ after Zoshk

River $2.7 \mathrm{~km}$ after Torghabeh

Shandiz drinking water (No. 1)

River $2.5 \mathrm{~km}$ after Zoshk

Shandiz drinking water (No. 2)

Torghabeh drinking water (No. 2)

River $2.3 \mathrm{~km}$ after Zoshk

Zshk drinking water (No. 3)

Upper Torghabeh drinking water (No. 1)

River $0.7 \mathrm{~km}$ after Zoshk

Zshk spring water (No. 1)

River $2.7 \mathrm{~km}$ after Zoshk

Shandiz drinking water (No.3)

River $0.8 \mathrm{~km}$ after Zoshk spring water

Lower Torghabeh drinking water (No. 1)

Shandiz drinking water near the mosque

Shandiz drinking water (No. 4)

Upper Torghabeh drinking water (No. 2)

River $5 \mathrm{~km}$ after Torghabeh

River $1.7 \mathrm{~km}$ after Zoshk

Lower Torghabeh drinking water (No. 2)

Lower Abrdh spring water

Shandiz drinking water (No. 5)

River of Shandiz waterfall (No. 1)

Lower Torghabeh drinking water (No. 3)

River $1.3 \mathrm{~km}$ after Zoshk

River beginning Zoshk

River $5.5 \mathrm{~km}$ after Torghabeh

Shandiz drinking water (No. 6)

River at Zoshk

River $5.9 \mathrm{~km}$ after Torghabeh

River $2.4 \mathrm{~km}$ after Torghabeh

River $0.5 \mathrm{~km}$ after Zoshk

Shandiz drinking water (No. 7)

River $1.5 \mathrm{~km}$ after Zoshk

Upper Torghabeh drinking water (No. 3)

Upper Abrdh drinking water (No. 4)

River $2.6 \mathrm{~km}$ after Torghabeh

River $1.2 \mathrm{~km}$ after Zoshk

Lower Torghabeh drinking water (No. 4)

Shandiz drinking water (No. 8)

Lower Torghabeh drinking water (No. 5)

River of shandiz waterfall (No. 2)

River $3.5 \mathrm{~km}$ after Abrdh

Lower Abrdh spring water

River $0.1 \mathrm{~km}$ after Lower Torghabeh

River $1.6 \mathrm{~km}$ after Zoshk

Upper Torghabeh spring water

River $0.2 \mathrm{~km}$ after Zshk

Torghabeh drinking water (No. 3)

River $4 \mathrm{~km}$ before Torghabeh

River $5 \mathrm{~km}$ before Torghabeh

River $0.5 \mathrm{~km}$ after Torghabeh

Zoshk spring water (No. 2)

Upper Torghabeh drinking water(No. 5)

Lower Torghabeh drinking water (No. 6)

Torghabeh drinking water (No. 4)

Spring water $1 \mathrm{~km}$ after Zoshk

Lower Torghabeh drinking water (No.7)

River $2.8 \mathrm{~km}$ after Zoshk

Torghabeh drinking water (No. 5)

River $0.2 \mathrm{~km}$ after Lower Torghabeh

$\mathrm{Q}_{\mathrm{Rn}}(\mathrm{Bq} / \mathrm{L}) \quad \mathrm{Q}_{\mathrm{Ra}}(\mathrm{Bq} / \mathrm{L})$

$0.660-0.099$

$0.940 \quad 0.000$

$1.040 \quad 0.180$

$1.180 \quad 0.170$

$\begin{array}{ll}1.299 & 0.018\end{array}$

$1.300 \quad 0.000$

$\begin{array}{ll}1.350 & 0.000\end{array}$

$1.400 \quad 2.190$

$1.540 \quad 0.056$

$1.960-0.000$

$1.641 \quad 0.163$

$\begin{array}{ll}1.763 & 0.000\end{array}$

$\begin{array}{ll}1.853 & 0.130\end{array}$

$\begin{array}{ll}1.937 & 0.308\end{array}$

$2.241 \quad 0.096$

$2.300 \quad 0.036$

$2.352 \quad 0.000$

$2.412 \quad 0.492$

$2.435 \quad 0.140$

$2.476 \quad 0.000$

$\begin{array}{ll}2.476 & 0.000\end{array}$

$2.630 \quad 0.854$

$2.698 \quad 0.070$

$\begin{array}{ll}2.850 & 0.000\end{array}$

$\begin{array}{ll}2.873 & 0.208\end{array}$

$\begin{array}{ll}2.870 & 0.000\end{array}$

$3.049 \quad 0.240$

$3.153 \quad 0.660$

$3.215 \quad 0.137$

$\begin{array}{ll}3.240 & 0.491\end{array}$

$\begin{array}{ll}3.269 & 0.000\end{array}$

$\begin{array}{ll}3.418 & 0.070\end{array}$

$3.492 \quad 0.000$

$\begin{array}{ll}3.619 & 0.787\end{array}$

$3.760 \quad 0.000$

$4.012 \quad 0.013$

$\begin{array}{ll}4.170 & 0.250\end{array}$

$4.200 \quad 0.133$

$\begin{array}{ll}4.231 & 0.000\end{array}$

$\begin{array}{ll}4.237 & 0.051\end{array}$

$4.254 \quad 0.000$

$4.375 \quad 0.000$

$\begin{array}{ll}4.729 & 0.000\end{array}$

$\begin{array}{ll}4.870 & 0.000\end{array}$

$4.895 \quad 0.300$

$\begin{array}{ll}4.980 & 0.000\end{array}$

$5.051 \quad 0.1108$

$5.050 \quad 0.316$

$\begin{array}{ll}5.081 & 0.059\end{array}$

$5.130 \quad 0.244$

$5.255 \quad 0.000$

$5.431 \quad 0.057$

$5.441 \quad 0.044$

$5.453 \quad 0.290$

$5.482 \quad 0.000$

$5.579 \quad 0.133$

$5.675 \quad 0.000$

$5.660 \quad 0.094$

$\begin{array}{ll}5.727 & 0.000\end{array}$

$\begin{array}{ll}6.141 & 0.087\end{array}$

$6.574 \quad 0.047$

$6.907 \quad 0.288$

$\begin{array}{ll}7.020 & 0.000 \\ 7.150 & 0.240\end{array}$

$\begin{array}{ll}7.150 & 0.240\end{array}$

$\begin{array}{ll}7.130 & 0.000\end{array}$

$\begin{array}{ll}7.770 & 0.240 \\ 7.587 & 0.093\end{array}$

7.587

0.093
Table 1: Continue

Water samples

Lower Torghabeh spring water (No. 1)

River $2.9 \mathrm{~km}$ after Zoshk

Zoshk spring water (No. 3)

River $4.5 \mathrm{~km}$ after Torghabeh

Torghabeh drinking water (No. 6)

Zoshk drinking water (No. 4)

Zoshk drinking water (No. 5)

Zoshk spring water (No. 4)

River $0.4 \mathrm{~km}$ after Zoshk

Zoshk drinking water (No. 6)

Lower Torghabeh drinking water (No. 8)

Zoshk spring water (No. 5)

Zoshk spring water (No. 6)

River $2.5 \mathrm{~km}$ after Torghabeh

River of Shandiz waterfall (No. 3)

Qelqeli spring water

Zoshk drinking water (No. 7)

Lower Torghabeh drinking water (No. 9)

Zoshk drinking water (No. 8)

Lower Torghabeh drinking water (No. 10)

Shandiz drinking water (No. 9)

Spring water $0.5 \mathrm{~km}$ after Zoshk

River $1 \mathrm{~km}$ before Zoshk

Lower Torghabeh Drinking water (No. 11)

River $2 \mathrm{~km}$ after Zshk

Zoshk spring water (No. 7)

River $1 \mathrm{~km}$ after Zoshk

Zshk spring water (No. 8)

Zshk spring water (No. 9)

Spring water $0.1 \mathrm{~km}$ after Zshk

Spring water $2 \mathrm{~km}$ after Zshk

Zshk drinking water (No. 9)

River $0.5 \mathrm{~km}$ before Zshk

Spring water at Zshk

River of Shandiz waterfall (No. 4)

Upper Abrdh drinking water (No. 6)

Lower Abrdh spring water (No. 2)

River $1.5 \mathrm{~km}$ after Abrdh

Spring water $0.7 \mathrm{~km}$ after Zshk

Spring water $1.5 \mathrm{~km}$ before Zshk

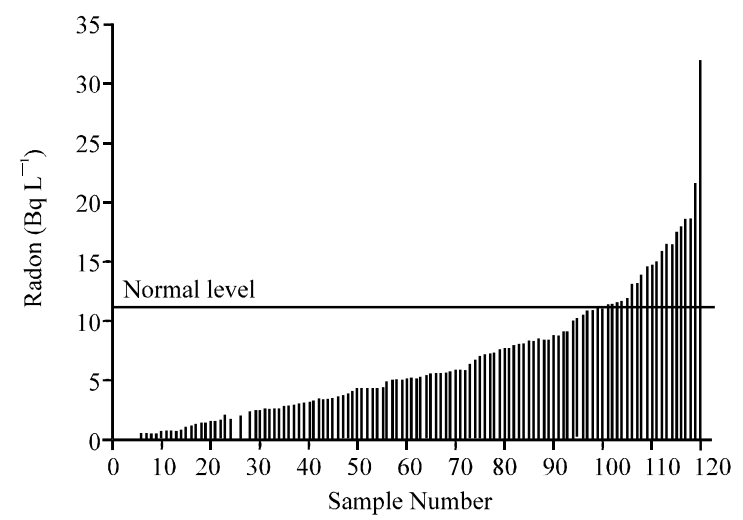

Fig. 3: The histogram of radon gas concentration in 120 water samples of Shandiz, Zoshk and Torghabeh regions

Radium in water samples: Figure 4 shows the histogram of radium concentration in different water samples as well 


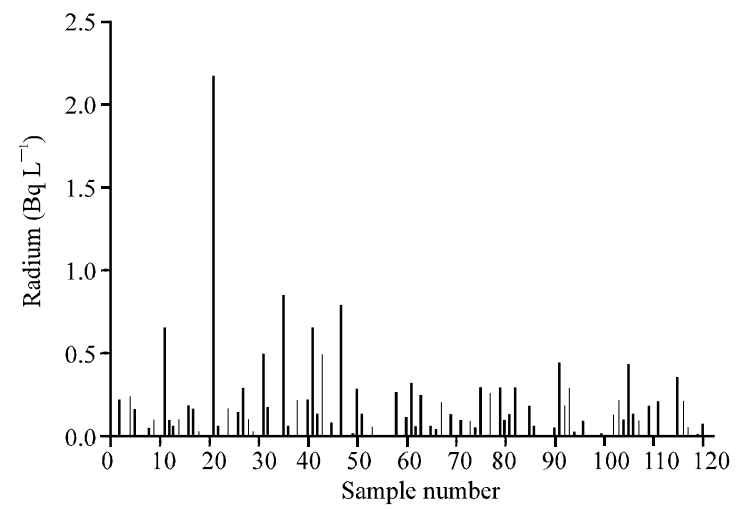

Fig. 4: The histogram of radium concentration in different water samples

as the data shown in 4 th column of Table 1. The radium concentration of samples were $<1 \mathrm{~Bq} \mathrm{~L}{ }^{-1}$ except sample number 21, drinking water of Shandiz region is about $1.87 \mathrm{BqL}^{-1}$.

\section{CONCLUSION}

Results of radon concentration in the water samples showed that only $14.67 \%$ sample concentrations were higher than the normal $11 \mathrm{~Bq} \mathrm{~L}{ }^{-1}$, set by United States Environmental Protection Agency (USEPA). About $148 \mathrm{~Bq} \mathrm{~L}^{-1}$ is limit amount of action or reaction that radon should be reduced. Radium concentration of all samples except sample number 21, drinking water of Shandiz were small and $<1 \mathrm{~Bq} \mathrm{~L} L^{-1}$. Therefore, radon and radium concentration in the water of the regions were not high and these were appropriate.

\section{REFERENCES}

Al-Kazwini, A.T. and M.A. Hasan, 2003. Radon concentration in jordanian drinking water and hot springs. J. Radiol. Prot., 23: 439-448.

Folger, P.F., P. Nyberg, R.B. Wanty and E. Poeter, 1994. Relationship between 222Rn dissolved in groundwater supplies and indoor 222Rn concentrations in some Colorado front range houses. Health Phys., 67: 245-253.

Kearfott, K.J., 1989. Preliminary experiences with 222Rn gas arizona homes. Health Phys., 56: 169-179.

Kendal, G.M. and T.J. Smith, 2002. Dose to organs and tissues from radon and its decay products. J. Radiol. Prot., 22: 389-406.

Khan, A.J., 2000. A study of indoor radon levels in Indian dwellings, influencing factors and lung cancer risks. Radiation Measurements, 32: 87-92.

Kusyk, M. and K.M. Ciesla, 2002. Radon levels in household waters in southern Poland. Nukleonika, 47: 65-68.

Li, X., B. Zheng, Y. Wang and X. Wang, 2006. A study of daily and seasonal variations of radon concentrations in underground buildings. J. Environ. Radioact., 87: 101-106.

Savidou, A., G. Sideris and N. Zouridakis, 2001. Radon in public water supplies in Migdonia Basin, central Macedonia, northern Greece. Health Phys., 80: $170-174$. 